\title{
ISLAM MODERAT DAN PROBLEM ISU KEISLAMAN KONTEMPORER DI MASJID NASIONAL AL-AKBAR SURABAYA
}

\author{
Muktafi \\ Universitas Islam Negeri Sunan Ampel Surabaya, Indonesia \\ E-mail: muktafi@uinsby.ac.id
}

\begin{abstract}
This article attempts to examine mainstreaming of the Moderate Islam together with the problem of contemporary Islamic issues at Al-Akbar National Mosque Surabaya. The article observes a number of issues such as liberalism, radicalism, and pluralism in the view of the Muslim preachers $\left(d_{\bar{a}} \boldsymbol{\imath}\right)$ of Al-Akbar National Mosque. The mainstreaming of the Moderate Islam has been a manifestation of recognition and reverence of the mosque management, especially the preachers in regard with a number of different religious entities in Islam. Responding to the issues, the preachers assert that the Moderate Islam contains not merely conformity with the context of sociocultural aspect, but also the manifestation of "Islamness" which is compatible with understanding of Abl al-Sunnab wa al-Jamáah. What is meant here by the Islamness is a characteristic of religiosity, which puts emphasis on three aspects, namely al-tawàsut, i'tidàl, and tawäzun. Commonly, the cultivation of moderatism values at Al-Akbar National Mosque rests on the process of teaching, study, and da'wa (preaching) activities. These activities have been implemented in persuasively subtle manner focusing on peaceful religious messages. The preachers argue that although moderatism has been usually seen as acceptance toward heterogeneity, it does not refer to any acknowledgement of such heterogeneity as a part of truth in one's belief.
\end{abstract}

Keywords: Al-Akbar National Mosque; Moderate Islam.

\section{Pendahuluan}

Agama secara etimologis berarti tidak kacau, atau dalam bahasa lainnya adalah teratur. Agama sebagai ketidakkacauan mengandung arti bahwa agama memuat seperangkat nilai keluhuran, kebajikan, dan 
kebaikan, yang berfungsi untuk mengatur aspek kehidupan manusia secara menyeluruh. Baik dalam konteks hubungan dengan sesamanya (horizontal) maupun hubungan dengan Tuhan (vertikal). ${ }^{1}$ Kenyataan bahwa agama mempunyai fungsi ganda, vertikal dan horizontal, meniscayakan atas terwujudnya kebaikan diri yang seimbang, baik secara personal sekaligus baik secara sosial. Kebaikan personal adalah kebaikan menyangkut interaksi diri dengan Tuhan (esoteris). Sedangkan kebaikan sosial adalah kebaikan menyangkut interaksi sosial diri bersama lingkungan (eksoteris).

Peran dan fungsi agama dalam kedudukannya sebagai pegangan hidup mensyaratkan kehadiran dirinya dalam kehidupan nyata. Pada tahap ini, agama mengambil bagian dalam ruang kehidupan, supaya dapat diterjemahkan sebaik dan sesempurna mungkin oleh setiap pemeluk dan penganutnya. Hanya, sifat agama yang memuat bahasa abstrak dan mistik, serta adanya kelemahan manusia dalam melakukan penalaran, pada akhirnya menyebabkan manusia mendapati keterbatasan untuk menafsirkan dan mengekspresikan perilaku agama mereka. Sebagai konsekuensinya, keterbatasan dan kelemahan tersebut menyebabkan agama diterjemahkan dalam bahasa dan simbol berbeda-beda. Pun seterusnya, simbol agama yang berbeda berbuntut pada konsep ketuhanan berbeda, dan pada puncaknya berefek pada ritual keagamaan yang berbeda. Dalam kerangka berpikir inilah, hukum realitas keragaman agama-agama dunia menemukan kebenarannya sebagai proses alamiah, sebagaimana hukum keragaman yang dialami entitas dan mahluk lainnya. Merujuk pada tesis Fritchof Schoun (1975), menyebut agama-agama lain sebagai agama adalah pengkuan atas adanya persamaan, dan menyebut agama dengan kata majemuk agama-agama, adalah wujud pengakuan atas perbedaan di antaranya. ${ }^{2}$

Begitupun dengan agama Islam, sejak awal kemunculannya, yakni ketika diperkenalkan dan diajarkan oleh Nabi Muhammad (570-632), Islam selaku agama penyempurna dari agama-agama samawi

1 Riza Zahriyal Falah, "Membentuk Kesalehan Individual dan Sosial Melalui Konseling Multikultural”, Konseling Religi: Jurnal Bimbingan Konseling Islam, Vol. 7, No. 1 (2016), 179.

${ }^{2}$ Fritchof Schuon, The Transcendent Unity of Religion (London: Harper Torchbook dan Row Publisher, 1975), 9. 
sebelumnya, ${ }^{3}$ sejauh ini telah menjelma sebagai satu realitas keyakinan yang sarat perbedaan. Baik dalam hal pemikiran, ajaran, dan aliran. Kompleksitas perbedaan tersebut nampak jelas dari dinamika sekte dan golongan keislaman masa kini, yang dari waktu ke waktu berkembang ke dalam banyak paham dan kelompok. ${ }^{4}$ Menariknya, setiap aliran dan kelompok mempunyai paradigma berlainan, yang pada gilirannya melahirkan praktik ritual keagamaan yang berlainan juga. Tak dapat disangkal, pada titik tertentu, perbedan tersebut sesekali menimbulkan gesekan dan benturan antaraliran berkepanjangan, sebagaimana yang terjadi antara sekte Sunnī dan Shīah. ${ }^{5}$ Namun tidak bisa ditampik pula, pada titik tertentu, keberagaman tersebut turut pula menimbulkan efek positif, karena semakin memperkaya khazanah keilmuan di internal keislaman, dan menjadi medium semakin meluasnya penyebaran Islam di jagat bumi.

Kenyataan bahwa keragaman Islam memantik perdebatan hingga pergesakan cukup panjang, terutama di tataran masyarakat akar rumput, pada gilirannya manarik perhatian banyak kalangan. Gagasan seputar bagaimana menengahi, menekan, atau bahkan menyudahi pergesakan antarkelompok islam, baik dalam hal pemikiran, sekte, dan alirannya, menjadi salah satu pokok pembicaraan berbagai kalangan. Layaknya Anthonio Giddens dengan gagasan the third way-nya, para cendekiawan dan pemikir Muslim dunia, termasuk di Indonesia, berusaha keras untuk memunculkan satu diskursus keislaman tengah. Satu ciri khas Islam yang tidak ekstrem kanan dan tidak juga ekstrem kiri. Dalam diskursus keislaman sekarang, mayoritas pemikir Muslim menafsirkannya dengan sebutan Islam moderat. Dalam bahasa Yūsuf al-Qardāāī, moderat adalah al-wast. yang berarti jalan tengah (middlepath atau middle-way). ${ }^{6}$

Begitupun di Indonesia, gagasan Islam tengah (the third way of Islam) diidentifikasi dengan sebutan Islam moderat. Islam yang diklaim sebagai hasil perasan dari term wasat dan ittidäl yang diserukan

\footnotetext{
${ }^{3}$ Syamsul Hidayat, 'Tafsir Qur'ān Indonesia tentang Agama-agama: Telaah Kitab alQuran dan Tafsirnya dan Kitab Tafsir al-Mishbab", Profetika: Jurnal Studi Islam, Vol. 17, No. 2 (2016), 49.

${ }^{4}$ Fachri Ali dan Bahtiar Effendy, Merambah Jalan Baru Islam Rekonstruksi Pemikiran Islam Indonesia Masa Orde Baru (Bandung: Mizan, 1986), 9.

5 Said Aqil Siradj, "Menggagas Teologi Perdamian Sunni-Shi'ah di Indonesia", Teosofi: Jurnal Tasawuf dan Pemikiran Islam, Vol. 3, No. 2 (2013), 320.

6 Al-wast diartikan oleh Hans Wehr sebagai middle-path, jalan tengah. Baca Hans Wehr, Modern Written Arabic (Gottingen: Otto Harrassowitz Verlag, 1979), 1248.
} 
langsung oleh Allah dan Rasul-Nya, Muhammad, sebagaimana tertulis dalam teks Q.S. al-Baqarah [2]: 143. ${ }^{7}$ Persisnya, Islam moderat dalam pengertian Islam di bumi nusantara adalah karakteristik Islam yang menjalin kesesuaian dengan konteks sosio kultur masyarakat pribumi. Berkenaan dengan ini, Syafii Maarif, cendekiawan Muslim besar Indonesia, menyebutnya sebagai keberislaman khusus dalam bingkai keindonesiaan. ${ }^{8}$ Islam yang menjunjung tinggi toleransi terhadap keseluruhan budaya, tradisi, dan adat lokal. Dalam diskursus lebih luas, selain menyimpan makna lokalitas, Islam moderat juga dimaknai sebagai respons para pemuka Islam Indonesia, khususnya kalangan ulama dan cendekiawan Muslim lintas organisasi, terhadap perkembangan isu-isu Islam kontemporer, yang dari waktu ke waktu semakin liar dan tidak terkendali. Baik yang liar ke jalur ekstrem kanan maupun ke jalur esktrem kiri.

Berkenaan dengan kajian ini, artikel ini merupakan studi yang berupaya melakukan deskripsi terhadap upaya pengarusutamaan Islam moderat sebagai respons kalangan pemikir dan cendekiawan, dalam hal ini semua pendakwah di lingkungan Masjid Al-Akbar Surabaya, terhadap isu keislaman kontemporer yang berkembang saat ini. Baik isu keislaman yang melandaskan mazhab pemikirannya pada ajaran ekstrem kiri maupun ekstri kanan, seperti halnya paham Islam liberal, radikal, plural, dan sejawatnya.

\section{Tinjauan Historis dan Konseptual Islam Moderat}

Term moderatisme bukan tema baru dalam sejarah pemikiran Islam. Perbincangan tentang moderatisme telah berlangsung cukup lama, terutama ketika Islam dihadapkan pada ancaman pergolakan pemikiran dan pergarakan, baik yang tumbuh di kalangan internal

\footnotetext{
7 "Dan demikian (pula) Kami telah menjadikan kamu (umat Islam), umat yang adil dan pilihan agar kamu menjadi saksi atas (perbuatan) manusia dan agar Rasul (Muhammad) menjadi saksi atas (perbuatan) kamu. Kami tidak menetapkan kiblat yang menjadi kiblatmu (sekarang) melainkan agar Kami mengetahui (supaya nyata) siapa yang mengikuti Rasul dan siapa yang membelot. Sungguh (pemindahan kiblat) itu terasa amat berat, kecuali bagi orang-orang yang telah diberi petunjuk oleh Allah; dan Allah tidak akan menyia-nyiakan imanmu. Sesungguhnya Allah Maha Pengasih lagi Maha Penyayang kepada manusia" (Q.S. al-Baqarah [2]: 143).

${ }^{8}$ Lihat buku Ahmad Syafi'i Ma'arif, Islam dalam Bingkeai Keindonesiaan dan Kemanusiaan: Sebuah Refleksi Sejarah (Bandung: Mizan, 2009), 45.
} 
maupun dari luar. ${ }^{9}$ Boleh dibilang, dalam kedudukannya sebagai satu paham keagamaan, baik dalam berpikir maupun bersikap, moderatisme adalah satu sintesa keislaman. Meminjam tesis dialektika Hegelian, moderatisme adalah kombinasi keislaman ideal yang lahir dari proses dialektika dari paham atau pemikiran Islam sebelumnya. Jika Islam haluan kanan adalah tesis atas karakteristik keberislaman yang kaku dan normatis, dan Islam kiri melalui kedinamisan dan kebebasanya adalah antitesis, maka moderatisme adalah perwujudan sintesis keduanya.

Jika merujuk pada penjelasan John L. Esposito, sangat sulit melakukan penelusuran jejak nyata moderatisme dalam keberislaman masyarakat Muslim secara praksis. ${ }^{10}$ Demikian dilandaskan pada kenyaataan sosio-historis, di mana Islam sendiri sejauh ini mengalami kesulitan untuk menempatkan dirinya dalam keragaman. Apakah itu keragaman dalam internal dirinya sendiri maupun keragaman menyangkut sistem kepercayaan lain di luar dirinya. Di tataran internal, moderatisme Islam menyisakan banyak kesangsian, karena sampai detik ini Islam sendiri belum mampu mengakomodir sekian perdedaan aliran, sekte, dan golongan, bahkan dengan bumbu konflik yang sudah bergulir dalam masa berkepanjangan. Begitupun terhadap sistem keyakinan di luarnya. Islam dinilai belum berhasil memperlihatkan perannya sebagai agama yang ramah terhadap humanisme universal. Tragedi 11 September 2001 seolah menjadi titik penjelas atas ketidakmampuan Islam berdamai dengan perbedaan. Dapat dibilang, pristiwa ini menjadi starting point di mana masyarakat non-Muslim dunia memiliki pandangan streotip terhadap Islam. ${ }^{11}$

Jika dikaji secara mendalam dan kritis, harus diakui bahwa term moderatisme dibangun tidak semata mengandaikan pada satu pemaknaan saja, karena sesungguhnya term ini masih mengandung banyak spekulatif dan banyak perdebatan. Hal ini dikarenakan term moderatisme sendiri tidak memiliki sandaran cukup jelas untuk dikaitkan pada Islam saja. Dalam arti yang lain, jika dilandaskan pada pluralitas dan keumuman maknanya, maka pemaknaan moderatisme itu bergantung sepenuhnya pada kaca pandang siapa dan kepada siapa

9 Debra Merskin, "The Construction of Arabs as Enemies: Post-September 11 Discourse of George W. Bush", Journal of Mass Communication and Society, Vol. 7, No. 2 (2004), 158.

${ }^{10}$ John L. Esposito, The Future of Islam (New York: Oxford University Press, 2010), 3.

${ }^{11}$ Merskin, "The Construction of Arabs as Enemies”, 158. 
lafal moderat ditujukan. Misal, dalam sejarah peradaban Barat, term moderatisme ditujukan kepada mereka yang keberislamannya sejalan dengan visi politik dan keagamaan Barat, Amerika pada khususnya. ${ }^{12}$ Bahwa pendefinisian moderat sebagai kesediaan diri mengamini sistem politik dan keagamaan Barat, misal sistem politik sekuler dan paham liberal dalam beragama, selain memang dicitrakan di atas bangunan makna aslinya, juga dilatari oleh kepentingan politik global yang tersembunyi rapi di baliknya (baca: globalisasi).

Dengan demikian—dijelaskan John L. Esposito-jika dibaca dari sudut pandang kepentingan global, khusunya menyangkut kepentingan politik Barat, maka faktor menggeliatnya term moderatisme di lingkup Islam sendiri, bisa dilihat dari empat hal, pertama, munculnya kecemasan dan kekhawatiran mayoritas penduduk Barat-terutama Amerika Serikat-terhadap menggeliatnya aksi radikalis dan terorisme. Dalam kaitan ini, tragedi 11 September 2001 adalah puncak dari segalanya, sehingga virus islamofobia menyebar luas di kalangan masyarakat Barat; kedua, pandangan buruk tentang Islam merupakan dampak dari minimnya pengetahuan mereka tentang Islam secara menyeluruh; ketiga, semakin memanasnya suhu politik antara Islam dan Barat, khususnya Amerika Serikat. Dalam kaitan ini, moderatisme adalah propaganda Barat yang sengaja ditabuhkan untuk melancarkan hegemoni politis terhadap Islam. Kondisi inilah yang digambarkan oleh Samuel Huntington, dengan teori besarnya, benturan peradaban (the clash of civilization), dan keempat, term moderatisme mewakili kepentingan para pemerhati Islam Barat yang gelisah sekaligus simpatik terhadap keberadaan Islam itu sendiri. ${ }^{13}$ Berangkat atas berbagai kenyataan ini, muncul segudang pertanyaan penting, benarkah konsep moderat menjalin relevansi dengan Islam? Jika demikian, adakah doktrin teologis yang mendasarinya? Untuk menjawab dua pertanyaan ini, maka berikut akan dipaparkan arti definitif moderatisme dalam pembahasan lebih mendalam dan terfokus.

Secara definitif, beberapa kalangan menilai penjabaran khusus tentang konsep moderatisme dalam Islam belum menemukan rujukan cukup jelas, bahkan dalam tataran ranah keislaman klasik sekalipun.

12 Masdar Hilmy, "Quo-Vadis Islam Moderat Indonesia? Menimbang Kembali Modernisme Nahdlatul Ulama dan Muhammadiyah", Miqot: Jurnal Ilmu-ilmu Keislaman, Vol. XXXVI, No. 2 (2012), 264.

13 Zuhairi Misrawi, Pandangan Muslim Moderat: Toleransi, Terorisme, dan Oase Perdamaian (Jakarta: Penerbit Buku Kompas, 2010), 61. 
Menariknya, di kalangan internal Islam sendiri, konsep moderat menuai banyak perdebatan, bahkan mengundang banyak pro-kontra, antara mereka yang setuju dan mereka yang menolak. Mereka yang menolak beranggapan bahwa term moderatisme adalah wujud propaganda Barat yang sengaja dilemparkan untuk melemahakan soliditas dan kesatuan Islam. Menurut mereka, konsep moderat adalah strategi Barat untuk membungkam pergerakan negara-negara Islam. Tak tanggung-tanggung, dalam pandangan kelompok ini, mereka yang mengakui atas kebenaran konsep moderat Barat dapat dikatagorikan penganut Islam banci. ${ }^{14}$ Keberislaman diri yang penakut membela sesama Muslim. Sebaliknya, kalangan yang setuju dengan konsep umum moderat melandaskan pandangan mereka terhadap visi ideal Islam, yakni Islam sebagai agama raḅah li al-älamin.

Terlepas dari pro-kontra di atas, secara umum banyak kalangan memahami moderatisme Islam sebagai paham keislamaan yang menjunjung tinggi kedamaian. Pengertian ini berlandaskan pada arti terminologinya, yang berarti; selalu menghindarkan perilaku atau pengungkapan yang ekstrem; kecenderungan untuk ke arah dimensi atau jalan tengah. ${ }^{15}$ Ekstrem berarti paling ujung, paling tinggi, paling sangat, paling keras, fanatik, dan hal yang keterlaluan. Adapun jalan tengah berarti bersikap adil, tidak condong ke (ekstrem) kanan dan tidak pula condong ke (ekstrem) kiri, baik dalam bersikap, berpikir, berucap, ataupun bertindak.

Dalam bahasa Inggris, term moderat memiliki kepadanan kata dengan moderate yang artinya; average in amount, intensity, quality, etc; not extreme (ratarata dalam jumlah, intensitas, kualitas, dan lain-lain; tidak ekstrem); of or having (su political) opinions that are not extreme (pandangan politik yang tidak ekstrem); keeping or kept within limits that are not excessive (menjaga dalam batas-batas yang tidak berlebihan) ${ }^{16}$ Adapun dalam bahasa Arab, moderat senantiasa diselaraskan dengan kata altawassut (tengah), al-ítidāl (adil) ${ }^{17}$ Sikap tawassut merepresentasikan pola keberislaman diri yang di satu sisi tidak memiliki keberpihakan pada kelompok Islam kanan, dan di sisi lain juga tidak condong pada kelompok kiri. Karena sikapnya ini, kebanyakan penganut Islam

${ }_{14}$ Ahmad Najib Burhani, "Islam Moderat adalah Sebuah Paradoks", Jurnal Ma'arif, Vol. 3, No. 1 (2008), 28.

${ }^{15}$ KBBI Online, (https://kbbi.web.id/) diakses pada 15 Januari 2015.

16 Tim Penulis, Oxford Advanced Learner's Dictionary (Oxford: Oxford University Press, 1994), 798.

${ }^{17}$ Hilmy, “Quo-Vadis Islam Moderat Indonesia?”, 264. 
normatif mengklaim moderatisme sebagai wujud keberislaman diri yang lemah, tidak memperlihatkan semangat keagamaan (ghirah diniyah) yang kuat. ${ }^{18}$

Sejalan dengan pembacaan di atas, Khaled Abu El Fadl dalam Rusdi (2009), menggolongkan term moderat sebagai lawan kata dari puritan. Puritan sendiri adalah satu ciri gerakan islamisme yang berorientasi-kekuasaan, menyerukan kembali kepada identitas Islam autentik melalui penerapan syariat Islam. ${ }^{19}$ Sedikit lebih utuh dari pembacaan Khaled Abu Fadl, Najib Burhani (2007) memaknai Islam moderat sebagai mid-position between liberalism and Islamism. Sebuah wujud keberislaman diri yang berada di tengah-tengah, antara liberalisme dan islamisme. ${ }^{20}$ Dengan demikian, dapat disimpulkan bahwa Islam moderat adalah wujud mediasi antar-dua tarikan Islam ekstrem, yakni Islam kanan dan Islam kiri. Tidak saling menyalahkan, tidak melakukan justifikasi kebenaran sepihak, senantiasa mengedepankan dialog, sehingga mencerminkan visi kerahmatan Islam. Jika sikap demikian dijadikan pijakan dalam beramal dan beragama, maka inilah konsep "Islam moderat" dalam makna sesungguhnya. ${ }^{21}$

Di Indonesia sendiri, diskursus Islam moderat telah banyak dimunculkan oleh banyak kalangan, khususnya para cendekiawan Muslim kontemporer, beberapa diantaranya adalah Azyumardi Azra, Syafii Maarif, dan Abdurahman Wahid (Gus Dur). Menurut Azra, moderat merupakan satu ciri keislaman yang mengandung karakter asli dari keberagamaan Muslim di Nusantara. Sedangkan Maarif mendefinisikannya sebagai satu karakter keberislaman diri dalam bingkai keindonesiaan. ${ }^{22}$ Hampir sama dengan keduanya namun dengan redaksi berbeda, Gus Dur mereduksi pengertian moderat berdasarkan makna keaslian Indonesia, bahwa Indonesia sebagai

\footnotetext{
18 M. A. Muqtedar Khan, "Islamic Democracy and Moderate Muslims: The Straight Path Runs through the Middle", Journal American Journal of Islamic Social Sciences, Vol. XXII, No. 3 (2005), 40.

${ }^{19}$ Rusli, "Gagasan Khaled Abu Fadl Tentang Islam Moderat Versus Islam Puritan: Perspektif Sosiologi Pengetahuan”, Jurnal Ilmu Ushuluddin, Vol. 8, No. 1 (2009), 116. ${ }^{20}$ Ahmad Najib Burhani, "Pluralism, Liberalism and Islamism: Religious Outlook of the Muhammadiyah Islamic Movement in Indonesia" (Tesis--Faculty of Humanities, University of Manchester, 2007), 16.

21 Asep Abdurrohman, "Eksistensi Islam Moderat dalam Perspektif Islam", Jurnal Rausyan Fikr, Vol. 14, No. 1 (2018), 29.

${ }^{22}$ Maarif, Islam dalam Bingkai Keindonesiaan, 45.
} 
negerinya kaum Muslim moderat. ${ }^{23}$ Jika disimpulkan, semua definisi di atas mengandaikan pada poin sama, bahwa Islam moderat adalah satu tradisi keberislaman yang selama ini diperlihatkan oleh mayoritas Muslim Indonesia. Muslim mayoritas yang hidup dan beraktivitas untuk dan di tengah masyarakatnya, mengupayakan perubahan dari bawah, dan menolak ekstremisme keberagamaan, kekerasan, dan terorisme. Dalam bahasa yang satire, Azra menggambarkan keberislaman Indonesia sebagai Islam with a smiling face. Islam yang penuh damai, sehingga tidak menemui pertentangan dengan semangat modernitas, demokrasi, HAM dan keseluruhan agenda pembangunan dunia modern lainnya. ${ }^{24}$

\section{Menelusuri Akar Teologis Islam Moderat}

Salah satu faktor pemicu adanya perdebatan seputar benartidaknya term moderatisme dalam Islam, ialah menyangkut konsistensi akar teologis moderatisme itu sendiri. Tidak sedikit kalangan mengklaim bahwa konsep moderatisme tidak memiliki sumber cukup jelas, termasuk di tataran pemikiran Islam klasik. ${ }^{25}$ Moderatisme hanya akal-akalan kalangan Barat untuk memperkeruh keberadaan Islam, sehingga jalan kebenaran Islam yang sesungguhnya menjadi sumir. Konsep moderat adalah propaganda akademisi Barat/orientalis yang menyimpan kepentingan politis untuk melemahkan semangat kesatuan dan persatuan kaum Muslim dunia. Alat untuk meninabobokan pergerakan negara-negara Muslim, sehingga mereka bersikap diam terhadap segala bentuk hegemoni Barat bersama antek-anteknya.

Namun, terlepas dari sekian pandangan di atas, tidak sedikit juga kalangan pemikir Islam kontemporer yang mengklaim bahwa konsep moderatisme Islam itu benar adanya. Islam membenarkan sikap moderat dalam beragama. Bahkan moderatisme sendiri adalah merupakan sikap keberislaman yang dianjurkan langsung oleh Allah dan Rasulnya. Demikian tercantum jelas dalam ajaran besarnya, baik yang bersumber dari al-Qur'ān maupun hadis. Bahwa konsep moderatisme Islam mempunyai akar teologi yang jelas, dan itu mutlak

23 Abdurrahman Wahid, Islamku Islam Anda Islam Kita: Agama Masyarakat Negara Demokrasi (Jakarta: The Wahid Institute, 2006), 60.

${ }^{24}$ Azyumardi Azra, "Bali and Southeast Asian Islam: Debunking the Myths", dalam Kumar Ramakrishna dan See Seng Tan (eds.), After Bali: The Threat of Terrorism in Southeast Asia (Singapore: World Scientific Publishing Co. Pte. Ltd, 2003), 45.

${ }^{25}$ Hilmy, "Quo-Vadis Islam Moderat Indonesia?", 263. 
kebenarannya karena diadopsi langsung dari sumber tertinggi Islam. Menurut Khaled M. Abou Fadl (2006), akar teologis Islam moderat dapat dilacak lewat dua preseden hukum utama islam, preseden alQur'ān yang senantiasa menyeru umat Islam untuk menjadi pribadi moderat, dan preseden al-Sunnah yang menasbihkan sosok nabi sebagai representasi keberislaman moderat paling ideal. Hal itu tercermin jelas dari sikap bijaknya tatkala dihadapkan pada suatu persoalan, maka Nabi selalu mengedepankan jalan tengah. ${ }^{26}$

Dari aspek teologis, kebenaran moderatisme Islam dilandaskan pada bunyi ayat al-Qur'ān, tepatnya Q.S. al-Baqarah [2]: 143, yang bunyinya sebagai berikut:

"Dan demikian (pula) Kami telah menjadikan kamu (umat Islam), umat yang adil dan pilihan agar kamu menjadi saksi atas (perbuatan) manusia dan agar Rasul (Muhammad) menjadi saksi atas (perbuatan) kamu. Dan Kami tidak menetapkan kiblat yang menjadi kiblatmu (sekarang) melainkan agar Kami mengetahui (supaya nyata) siapa yang mengikuti Rasul dan siapa yang membelot. Sungguh (pemindahan kiblat) itu terasa amat berat, kecuali bagi orang-orang yang telah diberi petunjuk oleh Allah; dan Allah tidak akan menyia-nyiakan imanmu. Sesungguhnya Allah Maha Pengasih lagi Maha Penyayang kepada manusia”.

Secara tekstual, kata wasat yang terdapat pada ayat di atas memang memiliki makna adil. Namun meski begitu, tidak kemudian menghilangkan kandungan makna moderatisme, karena adil sendiri adalah arti turunan dari sikap moderatisme yang ditafsirkan dalam pemaknaan lebih spesifik. Hal ini dilandaskan pada penjelasan Jalāl alDīn al-Mahallī (1389-1460) dan Jalāl al-Dīn al-Suyūṭ̂ (1445-1505) dalam karya monomentalnya, Tafsir Jalälayn (1459), bahwa wasat berarti umat pertengahan yang dalam tafsirannya memiliki pengertian adil dan pilihan. Pembacaan demikian juga diperkuat oleh pendapat para cendekiawan Muslim kontemporer, seperti Azyumardi Azra dan Din Syamsuddin. Menurut keduanya, term Islam moderat memiliki padanan kata dengan istilah ummah wasat atau al-din al-wasat. Begitupun juga dengan pemikiran Islam Iran, Ali Syariati, bahwa al-din al-wasat. mengandung arti bahwa Islam memosisikan dirinya di tengah, antara paham esoterisme Kristiani dan paham eksoterisme Yahudi. Kenyatan-kenyataan ini pula yang mendorong Burhani memberi penegasan, sebagaimana diuraikan dalam Zakiya Darajat (2017) bahwa

${ }^{26}$ Khaled Abou El Fadl, Selamatkan Islam dari Muslim Puritan, terj. Helmi Mustofa (Jakarta: Serambi Ilmu Semesta, 2006), 26. 
istilah al-din al wasat seperti yang dimaksudkan dalam Q.S. al-Baqarah [2]: 143 memiliki arti sebagai center atau heart, agama yang menjadi pusat dan jantung peradaban. ${ }^{27}$

Jauh berbeda dengan para pemikir sebelumnya, Nasaruddin Umar dalam Zakiya Drajat (2017) memiliki pandangan tersendiri dalam memaknai akar teologis moderat. Menurutnya, akar teologis moderat sesungguhnya sudah berada di balik kata Islam itu sendiri. Artinya, jika seseorang benar-benar menghayati keseluruhan ajaran Islam secara komprehensif dan holistik, maka dengan sendirinya orang tersebut akan menjadi moderat. Demikian karena Islam sendiri secara harfiah memiliki kepadanan kata dengan moderat, jalan tengah, tunduk dengan kritis, dan pasrah dengan nilai-nilai ajaran Islam. Itulah mengapa Islam dalam penamaan dirinya sebagai simbol kepasrahan totalitas terhadap sang penguasa (Allah) tidak dinamakan saläm, dan tidak juga disebuat istislam. Secara gramatikal Arab, lafal Islam adalah bentuk rubät $\mathbf{i}$ yang menegaskan kejalantengahan (moderate system). Sebutan ini sejalan apa yang disampaikan dan dipesankan Rasul pada umatnya, bahwa khayr al-umür awsatuba, sebaik-baik perkara adalah menempuh jalan tengah. ${ }^{28}$

Di Indonesia sendiri, pembahasan tentang teologi moderatisme Islam seringkali dikaitkan dengan teologi Abl Sunnah wa al-Jamäah, yang populer di kalangan masyarakat umum dengan sebuat Aswaja. Satu ciri keberislaman, baik dalam berpikir, bersikap, dan berperilaku yang melandaskan sepenuhnya kepada ajaran dan tuntunan Rasulullah, para sahabat nabi, para täbi ìn, dan segenap ulama-ulama terdahulu (al-salaf al-sălih) yang dipersepsikan dapat menjamin kemurnian ajaran Islam. ${ }^{29}$ Peletakan paham Aswaja sebagai akar teologis Islam moderat merujuk pada tiga ajaran dasar Aswaja, di mana kesemuanya diperas langsung dari tiga landasan berbeda yang bersumber dari al-Qur'ān. Tiga ajaran ini dikenal dengan trilogi Aswaja, yaitu: 1) al-tawassut berarti pertengahan; 2) ittidäl, memiliki arti tegak lurus, tidak berpihak ke kelompok kanan atau ke kelompok kiri, dan; 3) al-tawā̌un yang mengandung keseimbangan, tidak berat

27 Zakiya Darajat, "Muhammadiyah dan NU: Penjaga Moderatisme Islam di Indonesia", Hayula: Indonesian Journal of Multidisciplinary Islamic Studies, Vol. 1, No. 1 (2017), 89.

${ }^{28}$ Ibid., 90.

${ }^{29}$ Achmad Siddiq, Khittah Nahdliyyah (Surabaya: Khalista dan LTN-NU Jawa Timur, 2006), 27. 
sebelah antara aspek eksoteris duniawi dan aspek esoteris ukhrawi). ${ }^{30}$ Trilogi ajaran ini adalah pegangan dalam keseluruhan aktivitas hidup, baik dalam membangun relasi sosial dengan sesama, maupun membangun hubungan spiritual dengan Tuhan.

Dalam penjelasan lebih dalam, disebutkan bahwa ajaran moderat al-tawassut (pertengahan) merupakan satu wujud saripati keberislaman yang diperas langsung dari ayat al-Qur'ān, yakni Q.S. al-Baqarah [2]: 143. Prinsip ini mengandaikan pada sikap keagamaan yang menekankan pada jalan tengan (the third way), tidak condong pada jalur ekstrem kiri, dan tidak pula pada jalur ekstrem kanan. Misal, dalam dimensi aqidah tidak berpijak pada kelompok Jabarīyah dan tidak pula pada Qadarīyah. Dalam spiritualitas, tidak condong pada aspek esoteris dan tidak pula pada eksoteris. Dalam hal pemahaman, tidak condong pada naqlī (literal-tekstual) yang menjerumus pada pemahaman fundamentalis-radikal, dan tidak pula pada 'aqli (rasional dan logika) yang dapat menjerumuskan pada paham liberal. Adapun al-tawärun merujuk pada keseimbangan. Prinsip ini mendasarkan dirinya pada Q.S. al-Hadīd (57): 25, bahwa keberislaman moderatis itu harus dibangun atas dasar kesepadanan dan perimbangan, antara penguatan lahir dan batin. Sedangkan prinsip moderatis ittidāl meniscayakan pada sikap tegak lurus. Prinsip ini dilandaskan pada ayat al-Qur'ān, tepatnya Q.S. al-Māidah [5]: 8. Bahwa keberislaman harus dilandaskan pada keadilan, mengatakan benar jika benar dan mengatakan salah jika memang itu salah. Benar harus ditegakkan setinggi-tingginya tanpa melihat latar suku, agama, ras, bangsa, dan status sosialnya.

\section{Karakteristik Islam Moderat}

Dalam Konferensi Tingkat Tinggi Muslim Dunia (2018), disebutkan bahwa ada empat sikap beragama yang menjadi karakteristik Islam moderat, rasional, toleran, bertengggang rasa, dan tepa selera. ${ }^{31}$ Rasional berarti dapat dijangkau rasio atau sejalan dengan hukum-hukum akal. Bahwa moderatisme dalam berislam adalah senantiasa menempatkan akal sebagai patner agama. Akal

30 Abdul Muchith Muzadi, NU dalam Perspektif Sejarah dan Ajaran: Refleksi 65 Th. Ikut NU (Surabaya: Khalista, 2007), 69-71.

31 Kompas.com, Pemerintah Kenalkan Konsep Islam Moderat ke Selurub Penjuru Dunia (https://regional.kompas.com/read/2018/03/14/19311531/pemerintah-kenalkankonsep-islam-moderat-ke seluruh-penjuru-dunia), diakses pada 13/01/19. 
melalui kemampuan dan kecanggihan bernalarnya berkedudukan sebagai instrumen di mana bahasa-bahasa mistik agama diterjemahkan, ditafsirkan, dan dimaknai. Dengan peran akal, pesan agama yang sebelumnya berada dalam alam abstrak dapat dibumikan secara nyata ke dalam aspek kehidupan.

Adapun toleran dalam Kamus Besar Bahasa Indonesia (KBBI) diartikan sebagai suatu sikap atau sifat yang menanggang (menghargai, membiarkan, membolehkan) pendirian (pendapat, pandangan, kepercayaan, kebiasaan, kelakuan, dan sebagainya) yang berbeda atau bertentangan dengan pendirian sendiri. ${ }^{32}$ Berdasar pengertian ini, toleran dalam berislam yang moderat mengandaikan pada perwujukan sikap keberagaman yang senantiasa terbuka dan membuka diri pada setiap bentuk keagamaan yang di luarnya, baik itu menyangkut pemikiran, ritual, ajaran, dan sebagainya. Dalam diskursus keagamaan global, perilaku keberagaman yang toleran juga dibahasakan sebagai cara keagaman yang inklusif, yaitu satu perilaku keagamaan yang memiliki kecenderungan untuk melebur dengan penganut agamaagama lain di luar keyakinannya. Perlawanan dari inklusif adalah eksklusif. Kebalikannya, pola keberagaman eksklusif memiliki kecenderungan menutup diri. Mempunyai kesadaran yang rendah untuk melakukan kerjasama dengan golonga lain yang tidak sejalan dengan paham dan agama mereka. Hal penting yang perlu digarisbawahi di sini bahwa toleran dan inklusif bukan dalam arti prinsip, seperti halnya aqidah. Toleran dan inklusif dalam arti bersikap dengan sesama, bukan menyangkut konsep ketuhanan dan yang berbau asas lainnya.

Ciri ketiga Islam moderat adalah tenggang rasa. Secara etimologi, tenggang rasa memiliki arti dapat (ikut) menghargai (menghormati) perasaan orang lain. Pengertian ini memiliki kesamaan dengan Kamus Besar Bahasa Indonesia (KBBI). Adapun secara terminologi tegang rasa dipahami sebagai suatu sikap hidup dalam ucapan, perbuatan, dan tingkah laku yang mencerminkan sikap menghargai dan menghormati orang lain. ${ }^{33}$ Jika merujuk pada pengertian ini, maka moderat dalam berislam mensyaratkan atas perwujudan diri yang senantiasa menjunjung tinggi rasa kasih sayang, penghormatan, dan penghargaan kepada setiap orang yang memiliki latar (paham) keagamaan berlainan dengan kepercayaan kita. Sederhananya, moderat artinya bertenggang

\footnotetext{
${ }^{32}$ KBBI Online, (https://kbbi.web.id/) diakses pada 15 januari 2015.

${ }^{33}$ Ibid.
} 
rasa yang pada puncaknya menumbuhkan kesadaran, kesediaan, dan kesanggupan diri merangkulnya.

Ciri terakhir Islam moderat adalah tepa selera. Dalam Kamus Besar Bahasa Indonesia (KBBI) tepa selera merujuk pada pengertian; dapat merasakan (menjaga) perasaan (beban pikiran) orang lain sehingga tidak menyinggung perasaan atau meringankan beban orang lain; tenggang rasa dan toleransi. ${ }^{34}$ Jika mengacu pada pembacaan ini, dapat dibilang bahwa tepa selera sesungguhnya merupakan kombinasi dua sikap sekaligus, toleransi dan tenggang rasa. Tepa selera artinya di satu sisi mempunyai kesadaran untuk bersikap toleran, dan pada sisi bersamaan mempunyai tenggang rasa. Sederhananya, tepa selera adalah memiliki perhatian ganda, perhatian terhadap perasaan orang lain, dan perhatian terhadap perilaku diri.

Berbeda dari sebelumnya, Masdar Hilmy (2013) mencirikan Islam moderat pada lima aspek, antara lain: Pertama, adanya ideologi nonkekerasan dalam mendakwahkan Islam, bahwa Islam moderat menakankan pada cara-cara halus yang steril dari segala bentuk perilaku keras. Ciri ini-selain menjadi variabel penjelas-juga menjadi garis pemisah yang mengeluarkan dirinya dari aliran Islam lain yang bersifat kaku, terlebih aliran fundamentalis-radikal; Kedua, memiliki sikap keterbukaan pada modernisme beserta seluruh pembangunaanya, seperti halnya teknologi, ilmu pengetahuan, globalisasi, prinsip humanisme, dan sebagainya. Sikap ini berbeda jauh dengan kelompok Islam lain yang memilih menjaga jarak dan menolak produk pembangunan modernisme. Misal, kelompok Islam fundamentalis-radikalis Hizbut Tahrir (Indonesia), yang bersikeras menolak sistem politik demokrasi karena dianggap sebagai derivasi sistem kafar Barat; Ketiga, menempatkan akal rasio sebagai mitra dalam memahami ajara Islam, bahwa teks-teks Islam dalam fungsinya sebagai pegangan hidup harus disandingkan dengan aktivitas penalaran, karena tanpa diimbangi oleh akal maka agama hanya akan menjadi teks mati yang tidak dapat ditafsirkan dalam kehidupan nyata; Keempat, pemahaman terhadap sumber-sumber Islam yang dilakukan secara konstektual, bahwa apa yang termuat dalam al-Qur'ān dan Hadis tidak dipahami sekadar pada teksnya, namun dikombinasikan bersama aspek sosio-historis yang melatarinya; dan Kelima, penerapan ijtihad dalam proses peroduksi dan reproduksi yuriprudensi hukum Islam. Ciri ini sekaligus menjadi penegas atas semangat Islam moderat

${ }^{34}$ Ibid. 
yang menolak tertutupmya pintu ijtihad dalam aspek yuriprudensi Islam, sebagaimana dipahami kalangan Muslim tradisional pada umumnya. ${ }^{35}$

Hampir sama dengan Masdar Hilmy, namun dengan redaksi berbeda, Zaini Darajat (2017) mengelompokkan Islam moderat berdasar lima karakterisktik berikut: pertama, sikap penerimaan diri terhadap sistem demokrasi. Penerimaan terhadap demokrasi menjadi karakteristik Islam moderat yang paling fundamental, karena dalam demokrasi, selain merupakan sistem politik global, pun juga sistem sosial yang memuat kompleksitas nilai kemanusiaan, keseteraan, HAM, dan emansipasi. Demokrasi meniscayakan pada kesediaan diri hidup berdampingan dengan segala bentuk perbedaan, baik dalam agama, budaya, ras, suku, bangsa, bahkan politik sekali pun. Bagi kelompok Islam moderat, Islam tidak bertentangan dengan demokrasi. Menurut mereka, prinsip shürā yang termuat dalam ajaran islam, pada batasan-batasan tertentu, merupakan sinonim demokrasi; Kedua, penolakan terhadap agenda pendirian negara Islam, bahwa Islam moderat memiliki paradigma berpikir yang menekankan pada kondusivitas negara untuk menjamin kenyamanan dan kemashlahatan umat; Ketiga, tidak memaksakan penarapan prinsip tunggal keagaman sebagai perangkat hukum bernegara dan berbangsa, seperti halnya perda syariah dan sejenisnya. Terlebih jika proses penerapan tersebut dilandaskan pada pembacaan tradisional. Pemberlakukan peraturan berbau keagamaan tertentu yang dilakukan secara tradisional, dapat diklaim sebagai penyangkalan prinsip demokrasi dan tidak menghormati prinsip kemanusiaan dan HAM. Keempat, adanya pengakuan terhadap hak perempuan dan agama minoritas. Artinya, tidak melakukan kekerasan dan pengebirian hak perempuan yang megatasnamakan peran dan status sosial jenis kelamin tertentu, antara feminisme dan maskulinisme (baca: gender). Menghindari perlakuan diskriminatif yang ditimbulkan oleh sistem hierarki atau budaya patriarkhi. Ada kesediaaan diri untuk hidup bersama dan berdampingan, serta merangkul setiap kelompok minoritas, baik dalam lingkup agama, suku, bangsa, dan sejenisnya; Kelima menolak segala bentuk ajaran dan perilaku terorisme dan kekerasan, bahwa moderatisme senantiasa menjauhkan dirinya dari bersikap keras dan

\footnotetext{
35 Masdar Hilmy, "Whither Indonesia's Islamic Moderatism? A Reexamination on the Moderate Vision of Muhammadiyah and NU", Journal of Indonesian Islam, Vol. 7, No. 1 (2013), 25.
} 
radikal dengan kelompok ataupun golongan manapun. ${ }^{36}$ Moderatisme menekankan pada penggunaan cara-cara halus dan persuasif. Karena sifatnya yang halus dan persuasif ini, membuat moderatisme Islam menjadi lebih mudah diterima di tataran masyarakat.

Di Indonesia kriteria Islam moderat ini senantiasa disandingkan pada dua oraganisasi Islam besar, yakni Nahdhatul Ulama (NU) dan Muhammadiyah. Moderatisme NU dan Muhammadiyah tercermin jelas dalam paradigma keberislaman mereka, tidak condong ke ekstrem kanan dan tidak pula condong ke ekstrem kiri. Begitupun dalam hal politik dan sistem pemerintahan, keduanya memiliki penerimaan terhadap semangat pembangunan modernisme, serta penerapan demokrasi sebagai sistem bernegara dan berbangsa.

\section{Respons Para Dai Masjid Nasional Al-Akbar Surabaya terhadap Isu Islam Kontemporer}

Secara Sosiologis, kian pesatnya pola dan bentuk pemahaman Islam di era ini, sesungguhnya tidak lepas dari semakin kompleksnya realitas kehidupan manusia. Siklus globalisasi yang kian berjalan cepat, pada gilirannya telah melemparkan manusia pada kehidupan baru, yakni satu bentuk gaya hidup yang dipenuhi komodifikasi di segala aspek. Melalui komodifkasi, manusia mulai meninggalkan kebiasaan hidup lama, mereka berbondong-bondong memasuki kebiasaankebiasaan baru. Dalam hal bersikap dan berperilaku, yang awalnya menitikberatkan pada nilai, pada akhirnya berubah dan bergeser pada lambang dan simbol. ${ }^{37}$ Meminjam bahasa Clifford Geertz (19262006), agama pada tahap ini mengalami proses involusi, yakni suatu 'perumitan' macam dan bentuk yang muncul dikarenakan semakin beragamnya pola sikap dan perilaku penganutnya. ${ }^{38}$ Agama bukan lagi diartikan sebagai aktivitas pemenuhan spiritualitas normative, tapi lebih pada spiritualitas kreatif. ${ }^{39}$

Dalam Islam sendiri, proses involusi agama berjalan dalam ruang sosial yang sangat kompleks. Sebagian dari mereka ada yang lahir karena adanya perbedaan sudut pandang dalam mehamami sumber Islam. Ada yang bersifat normatif dan ada pula yang bersifat dinamis. Mereka yang dikenal normatif disebut Islam tradisionalis, sedangkan

${ }^{36}$ Darajat, "Muhammadiyah dan NU", 89.

${ }^{37}$ Jean Baudillard, Symbolic Exchange and Death (London: Sage, 1993), 19.

38 Abdullah, "Studi Tentang Modernisme Indonesia", Jurnal Sulesana, Vol. 8, No. 2 (2013), 28.

${ }^{39}$ David Harvey, The Condition of Postmodernity (Blakwell: Oxford, 1989), 45. 
yang cenderung dinamis disebut sebagai penganut Islam modernis. Dalam konteks diskursus Islam Indonesia, kelompok Islam modernis seringkali diidentifikasi pada keberadaan kelompok Muhammadiyah, ${ }^{40}$ sedangkan Islam tradisionalis diidentifikasi terhadap keberadaan NU. ${ }^{41}$ Sejauh ini, dua organiosasi tersebut menjadi potret paling mudah untuk melihat pengelompokan Islam tradisional dan Islam modern Indonesia. Selain dikenal sebagai dua organisasi Islam terbesar Indonesia, baik NU dan Muhammadiyah dinilai banyak kalangan sebagai reprsentasi Islam moderat Indonesia. Sehingga hal wajar jika keberadaan keduanya memperoleh sambutan baik di tengah masyarakat, baik dalam ritual dan doktrin ajarannya.

Kenyataan inilah yang kemudian melatari mengapa komposisi pendakwah di Masjid Nasional Al-Akbar Surabaya didominasi oleh dua kelompok ajaran ini (NU dan Muhammadiyah). Secara umum dapat dikatakan semua tokoh yang terdaftar sebagai pendakwah di Masjid Nasional Al-Akbar Surabaya memiliki latar dari dua organisasi keislaman ini. Jika bukan dari NU, pasti dari Muhammadiyah. ${ }^{42}$ Begitupun seterusnya. Hal demikian disebabkan oleh kenyataan keduanya yang sama-sama memiliki tradisi Islam moderat yang tumbuh berkembang dari akar kebudayaan, tradisi, nilai, dan sistem sosial nusantara. Baik NU maupun Muhammadiyah adalah realitas keislaman indegeneus yang menecerminkan realitas kultural Indonesia.

Selain dibentuk oleh paradigma berpikir, invlusi Islam juga dibentuk oleh faktor lain yang sifatnya politis. Pengelompokan Islam pada kutub ini didasari oleh sejarah peradaban Islam, yang pada masamasa tertentu diketahui bergelut aktif dengan kontestasi kekuasaan. Dua sekte Islam terbesar dunia, yakni sekte Islam Sunnī dan Islam Shī'ah, merupakan representasi kelompok keislaman yang lahir dari jalur ini. Sejarah mencatat, persaingan dan gesekan antara SunnīShī'ah bukan saja dipicu oleh faktor teologi an sich, tapi juga dilatari oleh pertikaian politis yang berkenaan dengan perebutan pengaruh dan kekuasaan, masalah-masalah yang bersifat marjinal. ${ }^{43}$ Dalam

\footnotetext{
40 Syekh Idahram, Sejarah Berdarah Sekte Salafi Wahabi (Yogyakarta: Pustaka Pesantren, 2011), 302.

${ }^{41}$ Einar M. Sitompul, Nabdlatul Ulama dan Pancasila (Jakarta: Pustaka Sinar Harapan, 1989), 64.

42 Sumarkan (Direktur Ibadah Periode 2007-Sekarang), Wawancara, Surabaya, 7 Desember 2015.

43 Ahmad Sahide, "Konflik Syiah-Sunni Pasca-The Arab Spring", Jurnal Kawistara, Vol. 3, No. 3 (2013), 323.
} 
diskursus keislaman kontemporer, kontestasi perebutan pengaruh Islam global, yang melibatkan Saudi Arabia selaku poros kekuatan Sunnī ortodoks, dan Iran sebagai poros kekuatan Shī'ah, keduanya merupakan representasi komodifikasi Islam abad ini, yang sama-sama lahir karena faktor politis di tataran internal Islam.

Di Indonesia, baik Shī'ah maupun Sunnī ortodoks keduanya tidak mendapat sambutan hangat di Indonesia, karena dinilai tidak relevan dengan konteks sosio keislaman Indonesia yang moderat. Bahkan berdasarkan fatwa MUI di beberapa daerah, misal di Jawa Timur, kelompok Shī'ah masuk dalam katagori paham terlarang, karena menyimpan ajaran-ajaran yang membingungkan umat, bahkan menyimpang dari Islam sesungguhnya. seperti halnya sikapnya yang membenci, mencela, dan mencerca para sahabat nabi. ${ }^{44}$ Fakta-fakta inilah yang kemudian mendorong banyak masyarakat untuk tidak dapat menerima keberadaan Shī'ah di Indonesia. Begitupun dengan Sunnī ortodoks, di Indonesia penganut Sunnī ortodoks dikenal dengan kelompok Wahabi. Secara aliran, kelompok ini masuk dalam katagori Sunnī. Namun, di Indonesia kelompok ini banyak mendapat tantangan, karena sifatnya yang ortodoks dan tidak bersikap moderat dengan konteks keislaman di Indonesia. Sikap Wahabi yang sangat anti terhadap tradisi dan ritual Islam lokal di Indonesia, selain karena ideologi mereka yang kaku dan sangat normatif, sehingga mudah menghukumi kafir dan sesat kelompok di luar mereka, ${ }^{45}$ menjadi alasan dominan mengapa kelompok Islam tidak begitu diterima di Indonesia.

Di kalangan pendakwah Masjid Nasional Al-Akbar sendiri, baik Shī'ah maupun paham Sunnī ortodoks tergolong sebagai paham 'terlarang'. Kedua paham ini tidak diperkenankan dipelajari, terlebih disebarkan kepada masyarakat secara umum, jamaah masjid pada khususnya. Keberislaman dalam konteks Indonesia adalah keislaman yang menjunjung tinggi semangat Islam moderat. Islam tengah yang tidak ekstrem kiri dan tidak pula ekstrem kanan. Islam yang tidak bertentangan dengan semangat prinsip tunggal Islam, al-Qur'ān dan Hadis, namun juga tidak bertentang dengan semangat keislaman lokal

44 Al-Musawi dan Syarafuddin, Dialog Sunnab-Syi'ah (Bandung: Penerbit Mizan, 2008), 34.

45 Muḥammad 'Ābid al-Jābirī, al-Mas'alah al-Thaqāfìyah (Beirut: Markaz Dirāsat alWahdah al-'Arabìyah), 140-141. 
di mana Islam berkembang. Islam yang mengakomodir spiritualitas kreatif yang digali dari nilai-nilai lokal masyarakat.

Berkenaan dengan ini, KH. Marzuki Mustamar dalam acara bedah buku, Untaian Permata Dalil-Dalil Amaliyah Ablus Sunnab Wal Jamaah, menuturkan:

"Lihat aliran-aliran dalam Islam seperti Mu'tazilah; Murjiah; Jabarīyah; Shī‘ah; dan lain-lain, apakah mereka semua mencerminkan demikian (moderat)? Tidak. Bahkan bagi sebagian orang itu sangat membingungkan karena saling serang sana-sini, sampai-sampai muncul klaim kebenaran hanya milik golongannya". ${ }^{46}$

Selain dua faktor di atas, komodifikasi Islam ke dalam gerakan atau kelompok tertentu juga dilatari oleh faktor (politik) transnasional. Mereka yang lahir dari jalur ini memiliki semangat besar membangkitkan kesadaran ummat Islam terhadap segala bentuk ancaman global yang diluncurkan melalui propaganda dan imperialisme negara-negara (kafir) Barat, Amerika pada khususnya. ${ }^{47}$ Menurut kelompok ini, musuh besar umat Islam adalah kekuatan-kekuatan imprialisme dan kolonialisme non-Muslim seperti Amerika. Mereka beralasan bahwa negera-negara tersebut selama ini berada di belakang Israel. Melindungi dan mendukung Israel menancapkan kekuasaan di negara Palestina. Untuk melawan hegemoni Amerika ini, maka umat Islam dunia harus bersatu melawan Amerika dan para sekutunya. Jalan satusatunya adalah menjalin kesatuan dan kebersamaan, melakukan perlawanan terhadap sistem neo-imperialisme Barat (seperti demokrasi), dan kembali sepenuhnya pada sistem Islam. Sistem demokrasi sendiri merupakan produk Barat yang tidak dibenarkan diberlakukan oleh negara-negara Islam. Sistem Islam yang dimaksud di sini adalah cita-cita tegaknya kembali khiläfah. ${ }^{48}$ Menurut kelompok ini, sistem khiläfah adalah satu-satunya sistem ideal yang dapat mengantarkan umat menjadi digdaya, seperti pada masa-masa khiläfah sebelumnya.

Dalam konteks diskursus Islam di Indonesia, kelompok Islam ini populer dengan sebutan Hizbut Tahrir Indonesia (HTI). Di Indonesia, gerakan Islam HTI berjalan sangat massif. Eksistensi dan penyebarannya tersusun rapi, sistematis, dan terstruktur.

\footnotetext{
${ }^{46}$ KH. Marzuki Mustamar, Wawancara, Gresik, 4 Desember 2015.

47 Masdar Hilmy, Islamism and Democracy in Indonesia: Piety and Pragmatism (Singapore: ISEAS, 2010), 18.

${ }^{48}$ Ibid., 120.
} 
Keberadannya tersebar luas di banyak struktur kenegaraan. Bahkan berkembang subur sampai di lingkungan pendidikan, baik dari tingkat sekolah menengah hingga ke dunia kampus. HTI memiliki gerak bebas di ruang publik. Tak tanggung-tanggung, seringkali mereka berteriak keras untuk mengganti ideologi negara dengan sistem khiläfah yang mereka dengungkan. Tak ayal, aksi dan gerakan mereka menuai kecaman, bahkan sesekali menimbulkan gesekan dan pertentangan di kalangan akar rumput.

Berkenaan dengan studi ini, berdasarkan data penelitian di lapangan, sikap pertentangan inilah yang juga diperlihatkan oleh kelompok pendakwah di Masjid Nasional Al-Akbar Surabaya. Dalam pandangan mereka, kesalahan elementer kelompok HTI terletak pada semangat perjuangan mereka yang bertentangan dengan konstitusional yang telah disepakati bersama sebagai Negara Kesatuan Republik Indonesia (NKRI). Cita-cita HTI untuk mengganti ideologi pancasila dengan sistem khilafah adalah perbuatan makar yang tidak dapat dibenarkan. Indonesia adalah miniatur rumah bersama dari berbagai golongan, ras, suku, dan kelompok agama. Karena merupakan rumah bersama, maka keberadaannya tidak boleh dipersempit oleh kepentingan sekelompok saja. Apalagi sebagaimana diketahui bersama, pancasila adalah ideologi universal yang di dalamnya memuat kompleksitas nilai, baik itu nilai agama, nilai sosial, nilai budaya, dan nilai kemanusiaan. Berkenaan dengan ini, $\mathrm{KH}$. Marzuki Mustamar menuturkan:

"Indonesia adalah rumah dari segala macam suku, ras, agama, dan budaya. Yang selama ini hidup berdampingan, aman, nyaman, tentram dan memberi kesejahteraan kepada seluruh penduduknya. Saya yakin jika itu diterapkan di Indonesia, maka Indonesia bisa saja bubar. Otomatis setelah itu harus membentuk dan mendirikan negara lagi. Apa kalian pikir mendirikan negara itu mudah? Tidak". ${ }^{49}$

Selain nama-nama di atas, involusi Islam dapat juga dikelompokkan berdasarkan tataran pemahaman yang dianut. Pada dimensi ini, Islam tumbuh berkembang dalam kelompok dan golongan lebih kompleks. Secara umum, beberapa di antaranya adalah paham liberalisme, fundamentalisme, radikalisme, eksklusivisme, transformative, pluralisme, inklusivisme, rasional, kontekstual, kultural dan sebagainya. Kesemua paham ini adalah wujud keragaman Islam

${ }^{49}$ KH. Marzuki Mustamar, Wawancara, Gresik, 4 Desember 2015. 
yang berpangkal dari tujuan yang sama, yakni dalam rangka merumuskan dan menemukan hakikat makna Islam dan keberislaman yang sesungguhnya. Namun demikian, seiring beragamnya corak pemahaman Islam, pada gilirannya kenyataan ini memunculkan persoalan keagamaan yang pelik. Baik di lingkup komunitas internal Islam itu sendiri, maupun dalam kaitannya dengan keberadaan sistem dan struktur sosial lebih luas, seperti ekonomi, politik, budaya, dan sebagainya. ${ }^{50}$

Di tataran internal Islam, ancaman serius datang ketika kemajemukan di sektor pemahaman menimbulkan friksi dan pergesekan. Hal ini diperparah oleh ketidakmampuan diri bersikap dewasa menyikapi sekian keragaman dan perbedaan pemikiran yang muncul dalam Islam sendiri. Ketidakmatangan diri bersikap toleran terhadap perbedaan, pada akhirnya menumbuhkan benih-benih permusuhan, justifikasi kebenaran, klaim sesat, dan lain sebagainya. Dalam konteks dinamika Islam di Indonesia, berbagai ancaman ini benar adanya. Beberapa paham keislaman yang berkembang saat ini, khususnya yang menganut paham Sunnī ortodoks, senantiasa menunjukkan sikap ketidakterimaan diri terhadap ajaran maupun ritual yang tidak berlaku dalam kelompok mereka. Celakanya, tidak cukup dengan itu, mereka juga menggolongkan kelompok di luar mereka sebagai ketidakbenaran dan kesesatan dalam beragama. Mereka yang tergabung dalam corak pemahaman ini, umumnya adalah penganut paham Islam tertentu yang cenderung fundamentalis, radikalis, dan eksklusif yang berakar dari paham Islam ortodoks ${ }^{51}$.

Sedangkan pada tataran lebih luas, persoalan terbesar muncul ketika keragaman pemikiran Islam tidak dapat berdamai dengan sistem dan struktur sosial di luarnya, karena dipicu oleh adanya sudut pandang dan pemahaman yang berbeda. Memperlihatkan penolakan terhadap adanya kedaulatan negara, sistem pemerintahan tertentu, dan lain sebagainya, seperti yang selama ini diperlihatkan kelompok Islam fundamentalis-radikal di Indonesia. Sebagaimana telah disinggung di depan, aliran paham keislaman ini lebih didominasi oleh jaringan Islam transnasional, Hizbut Tahrir, yang memiliki visi-misi mengubah sistem kekuasaan negara-negara dunia pada sistem tunggal khiläfah. Di

\footnotetext{
${ }^{50}$ Abuddin Nata, Peta Keragaman Pemikiran Islam di Indonesia (Jakarta: Rajawali Press, 2001), 6 .

${ }^{51}$ M. Zainal Abidin, "Islam dan Tradisi Lokal dalam Perspektif Multikulturalisme", Jurnal Millah, Vol. VIII, No. 2 (2009), 299.
} 
Indonesia sendiri, jaringan Hizbut Tahrir dikenal dengan Hizbut Tahrir Indonesia (HTI), yang saat ini secara resmi sudah dibubarkan pihak pemerintah karena menolak terhadap sistem demokrasi dan pancasila sebagai ideologi negara. ${ }^{52}$

Namun demikian, meski potensi ancaman dan persoalan di kalangan internal Islam menuntut kehati-hatian dan kewaspadaan, bukan kemudian sikap tersebut membuat akar keyakinan dan pondasi keagamaan diri menjadi goyah, apalagi sampai terlucuti. Yang marak terjadi sekarang adalah, banyak kalangan keagamaan memanfaatkan isu-isu fundamentalisme dan radikalisme sebagai pembenaran terhadap keberadaan isu-isu keagamaan lain, yang hakikatnya juga tidak dibenarkan dalam Islam, seperti halnya isu Islam pluralis dan Islam inklusif. Benar memang, menghukumi Islam fundamentalis dan radikalis yang bercokol pada pandangan Sunnī ortodoks, seperti halnya kelompok Wahabi, tidaklah tepat diterapkan dalam konteks keindonesiaan. Namun, tidaklah benar juga ketika isu Islam pluralis dan sejawatnya dijadikan percontohan tunggal, diproyeksikan sebagai jalan kebenaran di tengah maraknya sentimen Islam kanan. Kenyataan yang terjadi saat ini banyak kalangan menggugat keberadaan Islam fundamentalisme, tapi pada saat bersamaan mereka berdamai dengan pluralisme, atau bahkan menjadi bagian dari tokoh pluralisme. Paham pluralisme sebagai agama yang (dianggap) rasional, ${ }^{53}$ yang mendasarkan ajarannya pada percampuradukan agama satu dengan agama lain, jelas bertentangan dengan Islam. Percampuradukan agama-agama dunia sama kedudukannya dengan menganggap bahwa semua agama itu benar. Prinsip ini mutlak bersebrangan dengan prinsip Islam, karena jelas bahwa Islam adalah satu-satunya agama yang benar di mata Allah. Kaitannaya dengan isu pluralisme di sini, Marzuki Mustamar selaku salah satu informan menuturkan:

"Sangat tidak dibenarkan jika kita mencampur-adukkan antaragama karena alasan pluralisme. Bahkan kita tergolong sebagai ahl al-bid'ah jika melakukannya. Jika berpedoman pada Piagam Madinah dan kehidupan sosial masyarakat Madinah, maka pluralisme dapat didefinisikan sebagai bentuk penghargaan terhadap agama lain/perbedaan agama. Dan perlu diingat, bahwa

52 Abd. A'la, "Sikap Muslim Fundamentalis terhadap NKRI Antara Penolakan dan Penerimaan Setengah Hati”, Jurnal UNISIA, Vol. XXXIII, No. 73 (2010), 7.

53 Aziz, "Pluralisme Agama", dikutip dari Ghardhan Gharamleki, Muhammad Hassan, Phisolophical Theology. Makalah disampaikan pada seminar kelas Doktor pada Mata Kuliah Prof. Thoha Hamim, MA., Ph.D. tahun akademik 2008. 
perbedaan adalah sunnatullah, sehingga kita juga harus mengambil sikap serta mengimaninya sebagai takdir Allah. ${ }^{54}$

Satu rupa dengan isu pluralis, yaitu isu Islam liberal. Islam liberalis umumnya dimunculkan sebagai antithesis di tengah ketakutan mayarakat Muslim terhadap sintimen keagaman garis keras yang bercokol pada fundamentalisme dan radikalisme. Selain itu, Islam liberal juga diidentifikasi sebagai Islam rasional, penyematan ini ditujukan untuk menarik perhatian masyarakat atas bahaya Islam eksklusif yang bersifat normatif-tekstual, dan mengesampingkan semangat rasionalitas Islam. Tidak hanya itu, Islam liberal selain memiliki karakter progresif juga memiliki pandangan kritis terhadap segala bentuk praktik keagaman bersifat tradisional. Di Indonesia, keberadaan Islam liberal mengundang perdebatan cukup panas, bahkan penolakan di kalangan akar rumput. Namun demikian, pergerakannya yang masif, sistematis, dan terstruktur menjadikan paham ini menyebarluas ke banyak struktur. Mulai dari partai politik, organisasi keislaman, organisasi kemayarakat, lembaga pendidikan, dan sebagainya.

Sekurang-kurangnya ada beberapa faktor yang menyebabkan aliran Islam liberal tertolak keberadaananya, beberapa di antaranya: 1) Adanya semangat melakukan ijtihad kembali terhadap segala aspek Islam, jika sebelumnya pintu ijtihad tertutup maka Islam liberalis lebih memilih membuka kembali pintu ijtihad selebar mungkin, 2) Lebih mengedepankan subtansi agama daripada teks-teks keagamaan. Artinya, akal dan rasiolitas menduduki derajat lebih tinggi ketimbang teks keagamaan itu sendiri, baik al-Qur'ān maupun Hadis, 3) Kebenaran agama dilandaskan pada relativisme, bahwa setiap agama adalah benar, dan kebenaran dalam agama bersifat terbuka dan plural, 4) Karena semua agama adalah benar, maka setiap individu bebas menentukan agamanya masing-masing, 5) Melakukan sekularisasi di segala sektor, baik politik, pemerintahan, ekonomi, terutama dalam sektor agama. Sekularisasi mengandaikan pada pemisahan segala aspek kehidupan. Agama harus ditempatkan pada ruang dan kedudukannya, tidak boleh mencampuri atau dicampurkan dengan aspek lainnya, politik misalnya.

Berlandaskan aspek-aspek inilah, banyak kalangan menyebut Islam liberalis sebagai bentuk penyimpangan, termasuk dengan aqidah Ahl al-Sunnah wa al-Jamā'ah, sebagai paham mayoritas di Indonesia.

${ }^{54}$ K.H. Marzuki Mustamar, Wawancara, Gresik, 4 Desember 2015. 
Dalam bahasa lebih satire, kalangan dakwah Masjid Nasional AlAkbar Surabaya menyebut kehadiran aliran-aliran Islam kekinian, dalam konteks ini adalah pluralisme dan liberalisme, adalah wujud keislaman kontemporer yang meuncul dari derajat kepahaman yang belum käfah (totalitas). Katidaktahuan memahami Islam pada gilirannya melahirkan produk pemikiran yang tidak benar dan melenceng dari jalannya, yang hari ini kita kenal dengan pluralisme, liberalisme, sekulurisme, dan sebagainya. ${ }^{55}$

\section{Analisis Teoretis Penguatan Islam Moderat di Lingkungan Masjid al-Akbar Surabaya}

Harus diakui, diskursus keagamaan menyangkut tema keragaman (aliran) Islam adalah salah satu isu krusial kontemporer yang tidak saja menarik, namun juga penting untuk dibicarakan. Dikatakan menarik karena isu ini meyimpan ruang diskursif yang mengundang perhatian banyak kalangan. Baik dari kalangan teologis, pemikir, bahkan hingga kalangan akademisi. Adapun menjadi penting, karena di tataran sosiologis perdebatan seputar keragaman Islam, baik dalam hal pemikiran, pergerakan, maupun kelompok, memunculkan berbagai dinamika sosial dan pro-kontra. Persoalannya, tidak sedikit dari mereka yang kemudian menafsirkan teologi keberagaman Islam dengan sudut pandangan yang ekstrem. Akibatnya, pada momen tertentu Islam ditampilkan dengan wajah sangar, dikarenakan pambacaan diri yang cenderung normatif, radikal, dan fundamentalis. Pada momen lainnya, Islam mengalami pengaburan identitas, hal ini disebabkan oleh konstruksi pemahaman diri yang condong ekstrem kiri. Begitu liar hingga mencerabuti wujud dan makna autentitasnya.

Berdasarkan pada akar teologisnya, pada batasan-batasan tertentu, para pendakwah di kalangan Masjid Nasional Al-Akbar Surabaya mengakui kebenaran hukum keragaman agama, namun demikian tidak semua perbedaan dalam agama (Islam) itu dapat diklaim benar. Karena pada tataran praksisnya, tidak sedikit wujud perbedaan itu lahir dari sudut pandang dan pemahaman yang salah. Dalam kaitan ini, kalangan pendakwah di lingkungan Masjid Nasional Al-Akbar memandang, bahwa kemunculan aliran atau paham keislaman kontemporer seperti halnya kelompok fundamentalisme, liberalisme, radikalisme, pluralisme, sekularisme, kesemuanya adalah objektivikasi keislaman yang muncul karena adanya ketidaktahuan-untuk tidak

${ }^{55}$ Ibid. 
mengatakan salah-membaca dan menafsirkan teks-teks islam, antara condong ke arah ekstrem kanan dan ekstrem kiri. Idealnya, untuk terhindar dari keduanya dibutuhkan satu konstruksi pemahaman khusus yang dapat mengakomodir dua kutub tersebut, antara kutub kanan dan kutub kiri. Jika dikaitkan dengan studi ini, sikap pertengahan yang diperlihatkan oleh kalangan pendakwah Masjid AlAkbar Surabaya, dalam memahami realitas keragaman islam, merupakan representasi nyata konsep Islam moderat, bahkan dalam pengertian paling dasar. Karena sebagaimana makna terminologinya, moderat berarti jalan tengah.

Secara definitif, sebagaimana disinggung oleh Azyumardi Azra, bahwa keberislaman moderat adalah Islam with a smiling face. Islam yang penuh damai, sehingga tidak menemui pertentangan dengan semangat modernitas, demokrasi, HAM dan keseluruhan agenda pembangunan dunia modern lainnya. ${ }^{56}$ Moderat sebagai penerimaan terhadap modernitas, artinya kalangan pendakwah di lingkungan Masjid Nasional Al-Akbar tidak menutup diri dari perkembangan zaman, ilmu pengetahuan, dan sebagainya. Hal ini mereka tunjukkan dengan komposisi pendakwah, di mana sebagian dari mereka terdiri dari kalangan akademisi, bahkan beberapa di antaranya bergelar guru besar. Adapun moderat sebagai penerimaan terhadap demokrasi mengisyaratkan, bahwa dakwah yang dijalankan di Masjid Nasional Al-Akbar, selain memuat nilai keislaman, juga memiliki kesedian untuk menerima sistem demokrasi sebagai kesepahaman politik, baik dalam berbangsa maupun bernegara. Sedangkan moderat sebagai pengakuan terhadap Hak Asasi Manusia (HAM), meniscayakan terhadap keberislaman diri yang mengakui, menghargai, dan menghormati prinsip-prinsip kemanusiaan. Kaitannya dengan studi ini, secara spesifik penghormatan terhadap HAM di lingkungan Masjid Nasional Al-Akbar Surabaya, tercermin jelas dalam prinsip ajaran mereka yang menekankan pada konsep tasämuh, yang berarti toleran.

Bagi kalangan pendakwah di lingkungan Masjid Nasional AlAkbar Surabaya, Islam moderat adalah wujud keberislaman ideal, yang tidak saja sesuai dengan semangat ajaran Ahl al-Sunnah wa al-Jamā'ah, namun juga dengan semangat kehidupan masyarakat yang sangat menjunjung tinggi nilai-nilai lokalitas, seperti tradisi, budaya, dan sebagainya. Kelebihan Islam moderat dibanding dengan paham Islam

56 Azra, "Bali and Southeast Asian Islam", 45. 
lain di luaranya, secara umum ada pada prinsip dan ajarannya yang kental dengan semangat kasih sayang, ramah, santun, sejuk, dan senantiasa berdakwah dengan bikmah, mawizah hasanah. Sifat-sifat inilah yang senantiasa ditanamkan oleh jajaran pendakwah di lingkungan Masjid Al-Akbar Subaya, dalam upaya mengajarkan arti pentingnya merawat perbedaan, kerukunan, saling menghormati, dan menyemai persatuan umat di tengah perbedaan.

Sebagaimana komunitas pada umumnya, komposisi jajaran pendakwah di lingkungan Masjid Nasional Al-Akbar Surabaya memiliki latar berbeda. Secara status sosial, beberapa di antara mereka ada yang berasal dari akademisi, ada dari kalangan ulama, dan terdapat juga dari kalangan para ustaz. Begitupun dalam hal keorganisasiannya, mereka yang tergabung dalam pendakwah Masjid Nasional Al-Akbar Surabaya juga mempunyai latar berbeda-beda. Sebagian dari mereka ada yang berafiliasi dengan NU, dan adapula yang berafiliasi dengan Muhammadiyah. Dari keseluruhan ormas keislaman di Indonesia, secara umum formasi pendakwah Surabaya didominasi oleh dua organisasi besar ini. Namun demikian, meski didominasi oleh pendakwah dengan afiliasi NU dan Muhammadiyah, tidak otomatis dapat ditafsirkan bahwa pihak masjid menutup diri terhadap keberadaan ormas lainnya. Karena pada hakikatnya, perekrutan pendakwah di lingkungan masjid Al-Akbar tidak melihat latar platform ormas tertentu. Hal ini bertujuan untuk menghindari bias keberpihakan. Sikap seperti inilah yang senatiasa dibangun oleh pihak Masjid Nasional Al-Akbar Surabaya, dalam rangka menjaga komitmen mereka dalam menjunjung tinggi moderatisme diri. Bekenaan dengan studi ini, jika dikaitkan dengan term Islam moderat dalam pengertian konseptual, sikap universalitas yang diperlihatkan pihak Masjid Nasional Al-Akbar Surabaya di atas, merupakan pengandaian dari keseluruhan karakteristik Islam Moderat, bahwa moderatisme dalam berislam harus dilandaskan pada penerimaan semua golongan, tanpa terkecuali. ${ }^{57}$

Namun demikian, meski pihak masjid bersikap terbuka terhadap seluruh ormas islam, bukan kemudian setiap pendakwah memiliki kebebasan dan keleluasaan diri mengajarkan paham mereka. Terdapat batasan-batasan tertentu yang harus perhatikan. Berkaitan dengan ini, pihak masjid sepakat bahwa setiap kegiatan keagamaan yang dilakukan di lingkungan masjid, baik itu dalam bentuk kajian, ceramah, atau

${ }^{57}$ Hilmy, “Whither Indonesia's Islamic Moderatism?”, 25. 
diksusi keislaman, harus mengandung pesan-pesan menyejukkan. Tidak bermuatan cacian, cercaan, klaim benar-salah, terlebih jika muncul statemen penyesatan terhadap ajaran atau ritual lainnya. Jika dikaitkan dengan isu keislaman kontemporer, sikap ini mengandung pengandaian pada pemaknaan Islam moderat sesungguhnya. Bahwa moderat berarti menghindari segala bentuk ujaran kebencian, tidak melakukan truth claim. Senantiasa melihat perbedaan sebagai keniscayaan hidup yang harus diterima, dihormati, dan dihargai. ${ }^{58}$

Jika mendasarkan pada keseluruhan data penelitian yang berhasil dihimpun di lapangan, dapat dikatakan bahwa upaya penguatan atau pengarusutamaan Islam moderat di lingkungan Masjid Nasional AlAkbar Surabaya, secara umum berpusat pada penguatan di tataran ideologi. Upaya ini merupakan pengandaian atas aktivitas keagamaan yang berorientasi pada penanaman pengetahuan kepada seluruh masyarakat, jamaah masjid secara khusus, tentang kenyataankenyataan ikbtiläfỹah. Khususnya yang bersentuhan langsung dengan aspek sosial-pemikiran (furüryab). Jika merujuk pada ciri moderatisme, sebagaimana dijelaskan oleh Masdar Hilmy (2013), maka pengenalan dan pembelajaran ikbtiläfýyah di lingkungan Masjid Nasional Al-Akbar Surabaya, memiliki fungsi stretegis untuk membentuk sikap keislaman diri yang rasional-kritis. Kedua, penguatan di sektor struktural. Upaya di bidang ini lebih pada penguatan di tataran internal Masjid Nasional Al-Akbar Surabaya. Persisnya, mereka yang namanya tercantum sebagai anggota di struktural kepengurusan masjid, khususnya jajaran pendakwah, mempunyai komitmen bersama menjaga dan memperjuangkan nilai-nilai moderatisme di lingkungan Masjid AlAkbar Surabaya. Berkenaan dengan ini, semua jajaran pengurus masjid, sangat diwanti-wanti untuk tidak menyampaikan ajaran-ajaran keislaman yang dapat memicu pergesekan di tataran masyarakat, dan jamaah pada khususnya. Apalagi masjid dalam kedudukannya sebagai tempat ibadah memiliki fungsi sentral sebagai pemersatu umat. Bukan memecah belah dan membangkitkan amarah umat.

\section{Catatan Akhir}

Pengarusutamaan Islam moderat di lingkungan Masjid Al-Akbar Surabaya adalah wujud pengakuan dan penghormatan jajaran masjid, khususnya kalangan pendakwah, terhadap realitas keragaman (aliran) Islam. Berkenaan dengan ini, dalam pandangan pendakwah Masjid Al-

${ }^{58}$ Ibid., 25. 
Akbar Surabaya, Islam moderat bukan saja memuat keselerasan dengan konteks sosio-kultural masyarakat, namun juga wujud keberislaman yang sejalan dengan pemahaman Ahl al-Sunnah wa alJamā'ah. Keberislaman yang dimaksud di sini adalah satu karakteristik dalam beragama yang menitikberatkan pada tiga aspek, al-tawassut (pertengahan), itidäl (tegak lurus), dan tawäąun (keseimbangan). Trilogi ajaran inilah yang kemudian dijadikan pegangan oleh jajaran pendakwah untuk ditanamkan langsung kepada masyarakat di lingkungan masjid, khusunya kalangan jemaah. Secara umum, penanaman nilai-nilai moderatisme di lingkungan Masjid Nasional AlAkbar Surabaya bertumpu pada proses pengajaran, kajian, dan dan aktivitas dakwah yang dijalankan secara halus, persuasif, dan menggunakan pesan-pesan agama yang menyejukkan.

Pengarusutamaan Islam moderat di lingkungan masjid Masjid Nasional Al-Akbar Surabaya, baik sebagai ajaran maupun ritual, mereka pahami sebagai jalan tengah, tidak condong ke ekstrem kanan maupun ekstrem kiri. Dalam kaitan ini para pendakhwah masjid menolak terhadap isu-isu Islam kontemporer yang memiliki keberpihakan pada salah satunya. Seperti halnya Islam Islam radikal, Islam liberal, Islam pluralis, dan sejawatnya. Dalam kaitan ini kalangan pendakwah Masjid Al-Akbar berpandangan, meski moderatisme identik dengan penerimaan terhadap keragaman, bukan kemudian mengakui sekian perbedaan tersebut sebagai kebanaran dalam berakidah.

\section{Daftar Rujukan}

A'la, Abd. "Sikap Muslim Fundamentalis terhadap NKRI Antara Penolakan dan Penerimaan Setengah Hati", Jurnal UNISLA, Vol. XXXIII, No. 73, 2010.

Abdullah. "Studi tentang Modernisme Indonesia", Jurnal Sulesana, Vol. 8, No. 2, 2013.

Abdurrohman, Asep. "Eksistensi Islam Moderat dalam Perspektif Islam", Jurnal Rausyan Fikr, Vol. 14, No. 1, 2018.

Abidin, M. Zainal. "Islam dan Tradisi Lokal dalam Perspektif Multikulturalisme", Jurnal Millah, Vol. VIII, No. 2, 2009.

Ali, Fachri dan Effendy, Bahtiar. Merambah Jalan Baru Islam Rekonstruksi Pemikiran Islam Indonesia Masa Orde Baru. Bandung: Mizan, 1986. 
Al-Musawi dan Syarafuddin. Dialog Sunnah-Syi'ah. Bandung: Penerbit Mizan, 2008.

Azra, Azyumardi. "Bali and Southeast Asian Islam: Debunking the Myths", dalam Kumar Ramakrishna dan See Seng Tan (eds.), After Bali: The Threat of Terrorism in Southeast Asia. Singapore: World Scientific Publishing Co. Pte. Ltd, 2003.

Baudillard, Jean. Symbolic Exchange and Death. London: Sage, 1993. Burhani, Ahmad Najib. "Islam Moderat adalah Sebuah Paradoks", Jurnal Ma'arif, Vol. 3, No. 1, 2008.

----. "Pluralism, Liberalism and Islamism: Religious Outlook of the Muhammadiyah Islamic Movement in Indonesia". Tesis--Faculty of Humanities, University of Manchester, 2007.

Darajat, Zakiya. "Muhammadiyah dan NU: Penjaga Moderatisme Islam di Indonesia", Hayula: Indonesian Journal of Multidisciplinary Islamic Studies, Vol. 1, No. 1, 2017.

Esposito, John L. The Future of Islam. New York: Oxford University Press, 2010.

Fadl, Khaled Abou El. Selamatkan Islam dari Muslim Puritan, terj. Helmi Mustofa. Jakarta: Serambi Ilmu Semesta, 2006.

Falah, Riza Zahriyal. "Membentuk Kesalehan Individual dan Sosial Melalui Konseling Multikultural”, Konseling Religi: Jurnal Bimbingan Konseling Islam, Vol. 7, No. 1, 2016.

Harvey, David. The Condition of Postmodernity. Blakwell: Oxford, 1989.

Hidayat, Syamsul. 'Tafsir Qur'ān Indonesia tentang Agama-agama: Telaah Kitab al-Quran dan Tafsirnya dan Kitab Tafsir al-Mishbab", Profetika: Jurnal Studi Islam, Vol. 17, No. 2, 2016.

Hilmy, Masdar. "Quo-Vadis Islam Moderat Indonesia? Menimbang Kembali Modernisme Nahdlatul Ulama dan Muhammadiyah", Miqot: Jurnal Ilmu-ilmu Keislaman, Vol. XXXVI, No. 2, 2012.

"Whither Indonesia's Islamic Moderatism? A Reexamination on the Moderate Vision of Muhammadiyah and NU", Journal of Indonesian Islam, Vol. 7, No. 1, 2013.

----. Islamism and Democracy in Indonesia: Piety and Pragmatism. Singapore: ISEAS, 2010.

Idahram, Syekh. Sejarah Berdarah Sekte Salafi Wahabi. Yogyakarta: Pustaka Pesantren, 2011.

Jābirī (al), Muḥammad 'Ābid. al-Mas'alah al-Thaqāfìyah. Beirut: Markaz Dirāsat al-Waḥdah al-'Arabìyah.

KBBI Online, (https://kbbi.web.id/) diakses pada 15 Januari 2015. 
Khan, M. A. Muqtedar. "Islamic Democracy and Moderate Muslims: The Straight Path Runs through the Middle", Journal American Journal of Islamic Social Sciences, Vol. XXII, No. 3, 2005.

Ma'arif, Ahmad Syafi'i. Islam dalam Bingkai Keindonesiaan dan Kemanusiaan: Sebuah Refleksi Sejarah. Bandung: Mizan, 2009.

Merskin, Debra. "The Construction of Arabs as Enemies: PostSeptember 11 Discourse of George W. Bush", Journal of Mass Communication and Society, Vol. 7, No. 2, 2004.

Misrawi, Zuhairi. Pandangan Muslim Moderat: Toleransi, Terorisme, dan Oase Perdamaian. Jakarta: Penerbit Buku Kompas, 2010.

Mustamar, K.H. Marzuki. Wawancara. Gresik, 4 Desember 2015.

Muzadi, Abdul Muchith. NU dalam Perspektif Sejarah dan Ajaran: Refleksi 65 Th. Ikut NU. Surabaya: Khalista, 2007.

Nata, Abuddin. Peta Keragaman Pemikiran Islam di Indonesia. Jakarta: Rajawali Press, 2001.

Penulis, Tim. Oxford Advanced Learner's Dictionary. Oxford: Oxford University Press, 1994.

Rusli. "Gagasan Khaled Abu Fadl Tentang Islam Moderat Versus Islam Puritan: Perspektif Sosiologi Pengetahuan", Jurnal Ilmu Ushuluddin, Vol. 8, No. 1, 2009.

Sahide, Ahmad. "Konflik Syiah-Sunni Pasca-The Arab Spring", Jurnal Kawistara, Vol. 3, No. 3, 2013.

Schuon, Fritchof. The Transcendent Unity of Religion. London: Harper Torchbook dan Row Publisher, 1975.

Siddiq, Achmad. Khittah Nahdliyyah. Surabaya: Khalista dan LTN-NU Jawa Timur, 2006.

Siradj, Said Aqil. "Menggagas Teologi Perdamian Sunni-Shi'ah di Indonesia", Teosofi: Jurnal Tasawnf dan Pemikiran Islam, Vol. 3, No. 2, 2013.

Sitompul, Einar M. Nabdlatul Ulama dan Pancasila. Jakarta: Pustaka Sinar Harapan, 1989.

Sumarkan (Direktur Ibadah Periode 2007-Sekarang). Wawancara. Surabaya, 7 Desember 2015.

Wahid, Abdurrahman. Islamku Islam Anda Islam Kita: Agama Masyarakat Negara Demokrasi. Jakarta: The Wahid Institute, 2006.

Wehr, Hans. Modern Written Arabic. Gottingen: Otto Harrassowitz Verlag, 1979. 